\title{
Sustainable Iron-based Oxygen Carriers for Hydrogen Production - Real-time Operando Investigation
}

\section{Yoran De $\operatorname{VOS}^{1,5,6,7}$, Antonis VAMVAKEROS ${ }^{2,3,4}$, Dorota MATRAS ${ }^{5,6}$, Marijke JACOBS $^{1, *}$, Pascal VAN DER VOORT ${ }^{7}$, Isabel VAN DRIESSCHE ${ }^{8}$, Simon JACQUES ${ }^{2}$, Vesna MIDDELKOOP ${ }^{1}$, An VERBERCKMOES ${ }^{9}$}

${ }^{1}$ Sustainable Materials Management, Flemish Institute for Technological Research (VITO), Boeretang 200, $2400 \mathrm{Mol}$, Belgium

${ }^{2}$ Finden ltd., East St Helen Street 5, Abingdon, Oxfordshire, United Kingdom

${ }^{3}$ ESRF-The European Synchrotron, 71 Avenue des Martyrs, 38000 Grenoble, France

${ }^{4}$ Department of Chemistry, University College London, 20 Gordon Street, London WC1H OAJ, United Kingdom

${ }^{5}$ School of Materials, University of Manchester, Manchester, Lancashire M13 9PL, United Kingdom

${ }^{6}$ Research Complex at Harwell, Rutherford Appleton Laboratory, Harwell Science and Innovation Campus, Harwell, Didcot, OX11 OFA, United Kingdom

${ }^{7}$ Department of Chemistry, Center for Ordered Materials, Organometallics and Catalysis (COMOC), Faculty of Sciences, Ghent University, Krijgslaan 281 S3, 9000 Ghent, Belgium

${ }^{8}$ Department of Chemistry, Sol-gel Centre for Research on Inorganic Powders and Thin films Synthesis (SCRiPTS), Faculty of Sciences, Ghent University, Krijgslaan 281 S3, 9000 Ghent, Belgium

${ }^{9}$ Department of Materials, Textiles and Chemical Engineering, Industrial Catalysis and Adsorption Technology (INCAT), Ghent University, Valentin Vaerwyckweg 1, 9000 Ghent, Belgium

*Corresponding Author, Marijke.Jacobs@VITO.be

\begin{abstract}
In this work, a spray-dried Fe-based oxygen carrier with an in situ generated $\mathrm{Mg}_{1-\mathrm{x}} \mathrm{Al}_{2-\mathrm{y}} \mathrm{Fe}_{\mathrm{x}+\mathrm{y}} \mathrm{O}_{4}$-support was investigated during packed-bed chemical looping operation with methane at $900^{\circ} \mathrm{C}$. The evolution of the solid-state chemistry taking place in the oxygen carrier material was investigated in real-time with synchrotron X-ray diffraction while the spatial distribution of the phases was investigated using X-ray diffraction computed tomography (XRD-CT). These measurements revealed that some Fe-cations were systematically taken up and released from the spinel support. This take-up and release was shown to be strongly related with the oxidation state of the active phase. Although this take-up and release of Fe-cations decreased the amount of Fe-oxides active in the chemical looping process, the oxygen transfer capacity was still sufficiently high. The microstructure of the oxygen carriers along the length of the packed reactor bed was also investigated with scanning electron microscopy (SEM). The experiments indicate that the $\mathrm{MgFeAlO}_{\mathrm{x}}$ support with an extra Fe-based active phase is a promising material for oxygen carriers, as it forms a sustainable non-toxic, stable and green alternative to the typical Ni-based oxygen carriers for hydrogen generation by chemical looping.
\end{abstract}




\section{Introduction}

Hydrogen is a necessary component used in the chemical industry primarily for the production of bulk chemicals such as methanol and ammonia. Additionally, when it has high enough purity, it is utilized as a clean energy source for fuel cells [1]. Currently, the most economical and widely used method for hydrogen production is the steam methane reforming (SMR) process in which firstly syngas is produced $\left(\mathrm{CH}_{4}+\mathrm{H}_{2} \mathrm{O} \rightarrow \mathrm{CO}+3 \mathrm{H}_{2}\right)$ followed by a water-gas shift reaction $\left(\mathrm{CO}+\mathrm{H}_{2} \mathrm{O} \rightarrow \mathrm{CO}_{2}+\mathrm{H}_{2}\right)$ where the remaining $\mathrm{CO}$ in the syngas is used to reduce steam into pure hydrogen [2]. To fulfil the high energy demands of SMR, large amounts of feedstock (usually non-renewable) are burned outside the reactor tubes leading to large emissions of $\mathrm{CO}_{2}$. Furthermore, SMR makes use of Ni-based catalysts that can be harmful for the environment and pose a health hazard.

Chemical looping for Hydrogen generation (CLHG) is a promising approach for producing hydrogen from both conventional and renewable feedstock with steam. By splitting the process into alternating steps, a pure $\mathrm{H}_{2}$-stream is inherently separated from a $\mathrm{CO}_{\mathrm{x}}$ stream without additional separation costs. These alternating steps are enabled by the use of metal oxides that 'carry' oxygen from an oxygen rich stream (such as air or steam) to the fuel. These materials hence called oxygen carriers, consist most frequently of metal oxides based on $\mathrm{Ni}, \mathrm{Cu}, \mathrm{Co}, \mathrm{Mn}$ and/or Fe combined with suitable support materials. During each cycle in the CLHG process, the oxygen carrier is first reduced while transforming fuel to syngas (or to the total oxidation products, i.e. $\mathrm{CO}_{2}$ and $\mathrm{H}_{2} \mathrm{O}$ ) and the next step involves the production of pure hydrogen through the reaction with steam and the replenishment of the oxygen carrier's lattice oxygen. Chemical looping processes are usually designed for operation in fluidized-bed systems [3] where the use of particles with defined densities, shapes and sizes are necessary for optimal transport and mixing in the reactor system. Packed-bed operation is however also occasionally investigated, due to its avoidance of technical challenges (i.e. mainly related to high pressure gas-solid separation) [4,5]. Both oxygen carrier granules [6,7] and novel structured materials are being developed and validated for use in packed-bed chemical looping configurations [8-11].

The development of new oxygen carriers with the desired characteristics is a key challenge towards the industrial application of the chemical looping process. Also, it is essential that the oxygen carrier synthesis becomes economically viable. The resulting oxygen carrier should possess good thermal properties as well as high reactivity, while still maintaining sufficient mechanical and chemical stability under both reducing and oxidizing conditions. The OC should also maintain a sufficiently high oxygen transport capacity in order to minimize the oxygen carrier bed inventory. While developing oxygen carriers for a sustainable chemical looping process their toxicity and impact on the environment are also crucially important.

Ni-based oxygen carriers were very successful due to their good reactivity, conversion and mechanical stability. However, their relatively high cost, susceptibility towards S-containing impurities and the fact that they pose a health and environmental hazard are key drivers for developing the $\mathrm{Ni}$-free oxygen carrier materials. While $\mathrm{Cu}$ - and $\mathrm{Mn}$-based oxygen carriers are known to be less harmful to the environment compared to Ni-based oxygen carriers, they are most suitable for total oxidation of the fuel in the Chemical Looping Combustion process [12]. $\mathrm{Fe}$-based oxygen carriers have the same benefits as the $\mathrm{Cu}$ - and $\mathrm{Mn}$-based oxygen carriers while 
1 attractive candidates for a sustainable and cost-effective oxygen carrier. These materials can be 2 used for both syngas generation and total oxidation reactions and exhibit high activity in the 3 water splitting reaction [13-15] which is essential for the production of pure hydrogen in the 4 CLHG process.

5 The suitability of unsupported pure metal oxides as oxygen carrier particles for the chemical 6 looping processes are limited due to agglomeration, limited mechanical properties and sintering issues, which are all detrimental to fluidized-bed and even packed-bed operation. Therefore these active materials are usually combined with an inert support such as $\mathrm{TiO}_{2}, \mathrm{SiO}_{2}, \mathrm{Al}_{2} \mathrm{O}_{3}$, $\mathrm{ZrO}_{2}$-based, kaolin and more recently $\mathrm{CeO}_{2}$ [16-19] and perovskites [20-22]. Despite the increased interest in new support, $\mathrm{Al}_{2} \mathrm{O}_{3}$ is still widely used because of its low cost and its thermal and mechanical stability at high temperatures. Also $\mathrm{MgO}$-modified $\mathrm{Al}_{2} \mathrm{O}_{3}$ supports are widely in use for oxygen carrier development as these materials often possess increased resistance against sintering and agglomeration and improved regenerability due to their higher stability [23-28].

Increased reactivity with both methane [21,29] and the gasification products $\left(\mathrm{CO}\right.$ and $\left.\mathrm{H}_{2}\right)$ was obtained [30-32] and an improved agglomeration resistance was observed [30] when these supports were used for Fe-based oxygen carriers. We recently investigated the reactions which occur in $\mathrm{Al}_{2} \mathrm{O}_{3}$ - and $\mathrm{MgAl}_{2} \mathrm{O}_{4}$-supported Fe-based oxygen carriers inside a lab-scale batch fluidized-bed reactor within one cycle and during long-term operation. The composition of the oxygen carrier was extensively investigated during operation by ex situ XRD. It was confirmed that the reactions which occur between Fe-oxides and the $\mathrm{Al}_{2} \mathrm{O}_{3}$-support can be detrimental to chemical looping operation, especially when using only steam during oxygen carrier oxidation [33]. The reactions between the active phase and the support lead to $\mathrm{FeAl}_{2} \mathrm{O}_{4}$-formation [34] which can lead to deactivation or at least to a decreased oxygen transfer capacity. This is due to the decreased amount of active phase in each successive cycle, as steam is not able to oxidize the $\mathrm{FeAl}_{2} \mathrm{O}_{4}$-spinel. Employing the $\mathrm{MgAl}_{2} \mathrm{O}_{4}$-support for these oxygen carriers instead of $\mathrm{Al}_{2} \mathrm{O}_{3}$ can mitigate the formation of $\mathrm{FeAl}_{2} \mathrm{O}_{4}[3,15,34]$, although some Fe-ions can still be taken up in the $\mathrm{MgAl}_{2} \mathrm{O}_{4}$-support. Steam regeneration is however possible, and the amount of $\mathrm{Fe}$ in the support after regeneration stabilizes after several cycles to up to 60 cycles. We also observed an enhanced microstructure with smaller grains. However, a series of complex interactions occur which lead to Fe-ions being taken up in the spinel lattice of the support. This take-up could not be investigated ex situ which could be due to the material being slightly modified 
The LCT group of Ghent University also executed extensive research on $\mathrm{MgFeAlO}_{\mathrm{x}}$-supported iron based oxygen carriers, mainly with the goal of further developing the promising concept of Catalyst Assisted Chemical Looping [35-38]. They found that the $\mathrm{MgFeAlO}_{\mathrm{x}}$-support itself also exchanges oxygen in the chemical looping process when the oxidation state of the incorporated $\mathrm{Fe}$ changes in the chemical looping process [39]. At reactor temperatures below $750^{\circ} \mathrm{C}$, the iron initially present in the $\mathrm{MgFeAlO}_{\mathrm{x}}$-support remains in the spinel structure, while at higher temperatures Fe-segregation is observed that leads to some deactivation due to the increase in grain sizes and a decrease in specific surface area [39]. Their coprecipitated oxygen carriers show high activities for $\mathrm{CO}_{2}$ conversion to $\mathrm{CO}$, although some segregation of Fe from the $\mathrm{FeMgAl}$-spinel, the long-term formation of $\mathrm{Mg}_{\mathrm{x}} \mathrm{Fe}_{1-\mathrm{x}} \mathrm{O}$, and a loss in surface area and pore volume reduced the oxygen storage capacity and activity of the synthesized materials [40]. Their experiments up to 1000 chemical looping cycles show that the $\mathrm{MgFe}_{\mathrm{AlO}}$-support is very stable, and could be promising not only as an oxygen storage material for chemical looping (without the addition of an extra active phase) [40], but also as a redox active catalyst support material[41].

In situ XRD has already been applied in oxygen carrier and catalyst development [42] for investigating the complex solid-state reactions, especially during TPR, TPO and isothermal cycling [39]. It is less suitable for measurements during operations in a fluidized-bed setup as the particles will move too much during the reaction and there is less advantage in utilizing spatially-resolved synchrotron XRD. On the other hand, spatially-resolved XRD techniques are directly applicable in packed-bed operation $[43,44]$. In this paper we will extensively investigate the interactions which occur between $\mathrm{MgFeAlO}_{\mathrm{x}}$-support and the Fe-based active phase during chemical looping with the help of operando synchrotron XRD and spatially resolved XRD-CT [43-45]. The active-phase support interactions are related to the oxidation state of the active phase and the systematic incorporation and release of Fe-cations in and from the support were elucidated. After the reaction, the complete packed bed was embedded and the microstructure of the oxygen carriers was analyzed with SEM.

\section{Materials and methods}

\subsection{Materials preparation}

The oxygen carrier was synthesized by a spray drying method according to our previous work $[33,46]$. Briefly, for the MgFeAl OC, 60 wt. $\% \alpha-\mathrm{Fe}_{2} \mathrm{O}_{3}$ (Alfa Aesar, 98\% (metals basis), -325 mesh powder), 11.3 wt.\% MgO (MAF Magnesite, MagChem 30) and 28.7 wt.\% $\alpha-\mathrm{Al}_{2} \mathrm{O}_{3}$ (Almatis, CT3000SG) particles (molar ratio $\mathrm{MgO} / \mathrm{Al}_{2} \mathrm{O}_{3}$ is $1 / 1$ ) were dispersed in de-ionized water with the necessary dispersants. These suspensions were homogenized by milling in a planetary ball mill (Retsch, Pulverisette 5, Germany). After adding a suitable polymeric binder, the suspension was spray-dried. The chamber fraction collected underneath the cone was then sieved to obtain particles of suitable dimensions for an industrial CL-process inside an interconnected fluidized bed process. 
The particles were calcined at $500^{\circ} \mathrm{C}$ for 1 hour in air and subsequently sintered in air at $1175^{\circ} \mathrm{C}$ using a high temperature furnace (Bouvier, Belgium) to obtain suitable mechanical properties.

The development of the OCs, the selection of their sintering temperature and the resulting composition and physical properties were previously reported [33]. The particles which were used in this study had a crushing strength of $1.2 \mathrm{~N}$, a porosity $<5 \mu \mathrm{m}$ of $39.5 \%$ and a porosity between 5 and $50 \mu \mathrm{m}$ of $5.4 \%$ (cavity in the spray dried particles) as calculated from $\mathrm{Hg}$ intrusion porosimetry. They consist of $34.9 \% \alpha-\mathrm{Fe}_{2} \mathrm{O}_{3}, 63.5 \% \mathrm{Mg}_{1-\mathrm{x}} \mathrm{Al}_{2-\mathrm{y}} \mathrm{Fe}_{\mathrm{x}+\mathrm{y}} \mathrm{O}_{4}$ (denoted $\mathrm{MgFeAlO}_{\mathrm{x}}$ in this paper), $0.7 \% \alpha-\mathrm{Al}_{2} \mathrm{O}_{3}$ and $0.9 \% \mathrm{MgFe}_{2} \mathrm{O}_{4}$ as determined by Rietveld Refinement from ex situ XRD-diffractograms[33].

\subsection{Materials Characterization}

The microstructure of the oxygen carriers was investigated by scanning electron microscopy using a FEI NOVA Nanosem 450 with an energy dispersive spectroscopy (EDS) system on a polished cross-section of the embedded reactor tube inside an epoxy resin.

To characterize the phase composition of the oxygen carriers (ex situ) powder X-ray diffraction (XRD) patterns were collected using a Philips X'Pert diffractometer with PANalytical X'Pert Pro software with $\mathrm{CuK} \alpha(\lambda=1.5405 \AA)$ at $40 \mathrm{kV}$. The identification of the crystalline phases was done by comparison of the peaks and the profile data in the diffractograms with the PDF2 database (2015). Rietveld refinement was executed utilizing aforementioned software using crystal structure models taken from the Inorganic Crystal Structure Database (ICSD), maintained by the Fachionformationzentrum and Gmelin-Institut, Germany.

\subsection{Operando characterization by synchrotron XRD-CT}

Operando XRD measurements were performed at the ESRF ID15A beamline using a monochromatic beam of $95 \mathrm{keV}$ (corresponding to a wavelength of $0.1305 \AA$ ) focused to a spot size of $45 \mu \mathrm{m} \times 18 \mu \mathrm{m}(\mathrm{H} \times \mathrm{V})$. Oxygen carrier particles were placed inside a quartz tube (with an OD of $6 \mathrm{~mm}$, ID of $5 \mathrm{~mm}$, and $10 \mathrm{~mm}$ length) and supported between a quartz porous plate and quartz wool. The capillary reactor was mounted into a gas delivery stub, itself mounted to a standard goniometer (to enable alignment). The goniometer was fixed to a rotation stage set upon a translation stage to facilitate the movements required for the CT measurements. The heating process was carried out using an ID15A custom-built furnace positioned around the capillary reactor. 2D diffraction patterns were collected using a Pilatus3 X CdTe 300K hybrid photon counting area detector. The acquisition time for the single point measurements was 500 ms per point during reduction and oxidation. Pure gases of $\mathrm{CH}_{4}$, and $\mathrm{He}$ were delivered to the reactor by (Brooks) mass flow controllers. The reaction was performed at $900^{\circ} \mathrm{C}$ and atmospheric pressure. The outlet gases were analyzed using an Ecosys portable mass spectrometer (see Figures S1 and S2 in the supporting information). The conditions used were $10 \mathrm{sccm} \mathrm{CH} \mathrm{CH}_{4}$ with $40 \mathrm{sccm} \mathrm{He}$ for the reduction and $50 \mathrm{sccm} 5 \% \mathrm{O}_{2}$ in $\mathrm{He}$ for the oxidation. During reduction, single point XRD measurements were taken at three representative heights inside the reactor bed (see positions indicated in Figure 1) at intervals of 1.2 minutes at each position. Measurements were continuously performed until the result of each XRD pattern indicated the complete reduction of the oxygen carrier bed (a little bit more than 50 minutes). 
1 the reactor bed until the material indicated beginning transformation to $\mathrm{Fe}_{2} \mathrm{O}_{3}$. In this way we 2 were able to ensure a gradient of active phases through the oxygen carrier bed in order to check 3 variations of microstructure across the bed. An XRD-CT slice was recorded at position 3 of the 4 packed bed before reaction, after 20 and 40 minutes of reduction and after oxidation with 161 5 translation steps (translation step size of $50 \mu \mathrm{m}$ ) covering $0-180^{\circ}$ angular range, in steps of $6 \quad 1.5^{\circ}$ (i.e. 120 tomographic angles/line scans). In order to spatially capture the solid-state 7 chemistry during these measurements, the reactor was flushed with He. The acquisition time 8 per point was $50 \mathrm{~ms}$ and each XRD-CT lasted approximately $20 \mathrm{~min}$. The whole experimental 9 procedure is given in Figure S4 in the supporting information. The detector calibration was 10 performed using a $\mathrm{CeO}_{2}$ NIST standard. Every 2D diffraction image was converted to a 1D 11 powder diffraction pattern after applying an appropriate filter (i.e. $10 \%$ trimmed mean filter) to 12 remove outliers using pyFAI [47,48]. These one-dimensional diffraction patterns were then 13 used for point in time operando XRD-maps in order to investigate the chemical looping 14 reactions and the interactions between the support and active phase. The final XRD-CT images 15 (i.e. reconstructed data volume) were reconstructed using the filtered back projection algorithm.

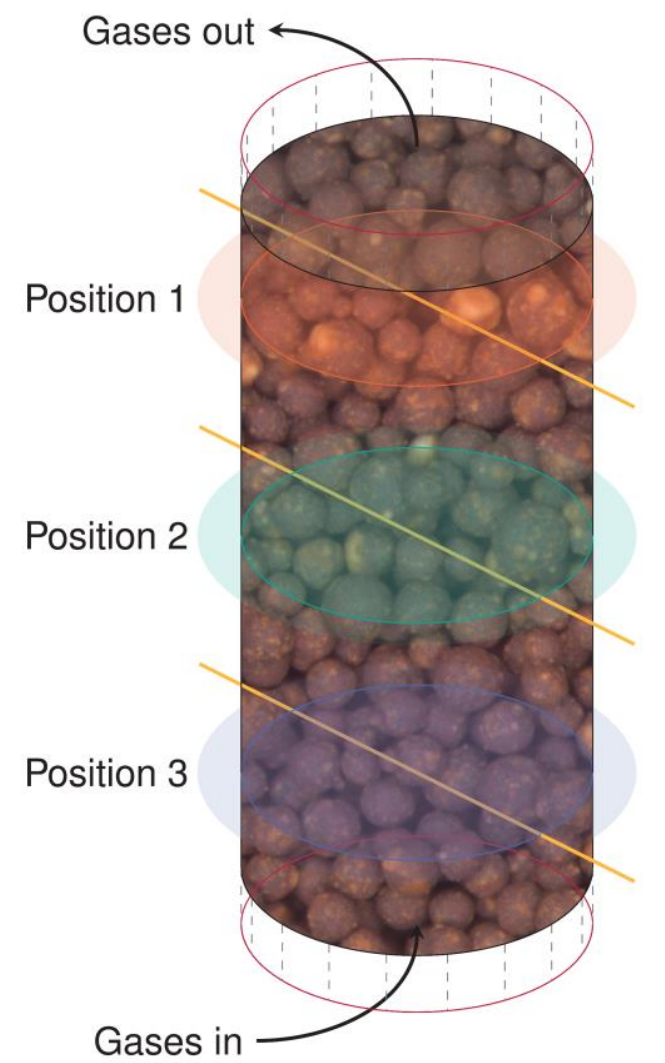

17 


\section{$1 \quad 3 \quad$ Results and discussion}

\section{$2 \quad 3.1 \quad$ Active phase reactions}
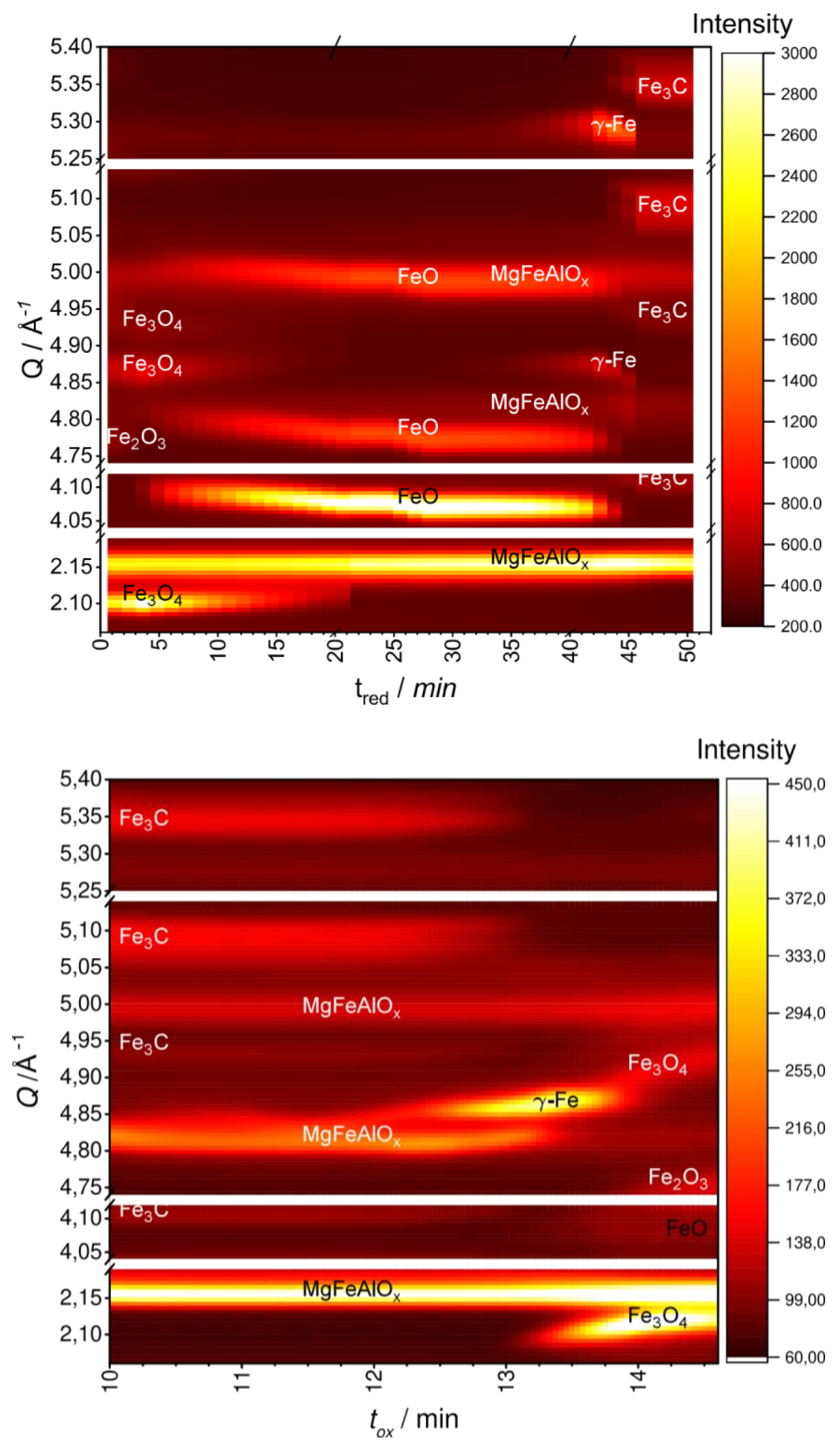

Figure 2: Point in time operando synchrotron XRD map constructed from diffraction patterns of (top) the

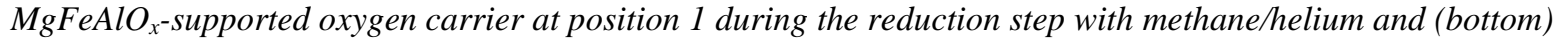
the final minutes of the oxidation step at position 2 with oxygen/helium, in the packed bed at $900^{\circ} \mathrm{C}$. For explanation on position locations, see Figure 1. 
Figure 2 shows the point-in-time operando synchrotron XRD-map of the $\mathrm{MgFeAlO}_{\mathrm{x}}$-supported oxygen carrier during introduction of methane (top) at position 1 in the packed bed and during the final minutes of the introduction of oxygen (bottom) at position 2 in the packed bed at a reactor temperature of $900^{\circ} \mathrm{C}$. The evolution of the phases at these positions indicate that the reaction from the Fe-based oxygen carrier occur sequentially. In 3 to 4 minutes, the $\alpha-\mathrm{Fe}_{2} \mathrm{O}_{3}$ transforms to $\mathrm{Fe}_{3} \mathrm{O}_{4}$. After 22-23 minutes $\mathrm{Fe}_{3} \mathrm{O}_{4}$ completely reduces to $\mathrm{FeO}$. At around 45 minutes, the reduction to $\gamma$-Fe finalizes. This Fe leads to carbon depositions due to a methane splitting reaction which is catalyzed by Fe. The carbon which is being deposited in the bed reacts with the $\mathrm{Fe}$, when sufficiently present, and $\mathrm{Fe}_{3} \mathrm{C}$ is formed. During oxidation, it takes a significant amount of time ( 12 minutes) before phase changes occur at position 2 in the packed bed reactor. This is due to the high reactivity between oxygen, introduced in the bed and the Fe-based active phases. All oxygen is taken up and the reaction front is moving along the axis of the bed. $\gamma$-Fe forms after 12 minutes. After 13 minutes $\mathrm{Fe}_{3} \mathrm{C}$ is depleted from the oxygen carrier and $\mathrm{Fe}_{3} \mathrm{O}_{4}$ forms. A very minor amount of $\mathrm{FeO}$ is detected while $\mathrm{Fe}_{3} \mathrm{O}_{4}$ significantly accumulates in the OC. At 14 minutes, $\mathrm{Fe}_{2} \mathrm{O}_{3}$ also starts to form and the $\mathrm{O}_{2}$-introduction is stopped at around 14.5 minutes.

Several peak shifts accompany the chemical reactions which occur in the reactor bed, especially during the transformation of $\mathrm{Fe}_{3} \mathrm{O}_{4}$ to $\mathrm{FeO}$. The diffraction peaks of the $\mathrm{Fe}_{3} \mathrm{O}_{4}$ phase shift to slightly higher Q-values while the diffraction peaks related to the $\mathrm{FeO}$ phase significantly shift to lower Q-values, indicating a change in lattice parameter and thus a change in composition of the respective phases. The long-term experiments executed on a similar material by Buelens et al. also displayed a shift in $\mathrm{FeO}$-peak after long-term cycling (with $10 \% \mathrm{H}_{2}$ in $\mathrm{He}$ for the reduction and $40 \% \mathrm{CO}_{2}$ for the oxidation) [40]. They explain this shift observed by ex situ XRD after 200 cycles by the formation of a Fe-rich $\mathrm{Mg}_{\mathrm{x}} \mathrm{Fe}_{1-\mathrm{x}} \mathrm{O}$-phase which then partially explains their loss of activity and oxygen storage capacity [40]. In our case, the continuous shift from higher $\mathrm{Q}$ values to lower $\mathrm{Q}$-values during the transformation of $\mathrm{Fe}_{3} \mathrm{O}_{4}$ to $\mathrm{FeO}$ in the first reduction step of the oxygen carrier is an indication of to the non-stoichiometry of the pure iron oxide. Figures S5 and S7 in the supporting information respectively show the XRDdiffractograms during the reduction step of the $\mathrm{OC}$ and the evolution of the areas and locations of the (111) and (002) reflections of this phase. Their respective locations and areas, together with the absence of a $\mathrm{MgO}$ peak after the formation of $\gamma$-Fe indicate that the shift observed in our material is only due to the non-stoichiometry of the wustite $(\mathrm{FeO})$ phase. Wustite $(\mathrm{FeO})$ is a well-known non-stoichiometric oxide, and also magnetite $\left(\mathrm{Fe}_{3} \mathrm{O}_{4}\right)$ and hematite $\left(\mathrm{Fe}_{2} \mathrm{O}_{3}\right)$ show homogeneity ranges where there exists non-stoichiometry. The peak shift of the FeO-phase during reduction indicates an increase in lattice parameter which can be explained by the reduction of the material. The phase initially contains more $\mathrm{Fe}^{\mathrm{III}}$, which has a smaller size compared to $\mathrm{Fe}^{\mathrm{II}}$. During reduction this $\mathrm{Fe}^{\mathrm{III}}$ is converted to $\mathrm{Fe}^{\mathrm{II}}$ and the size of the lattice parameter increases. After complete formation of $\mathrm{FeO}$ is attained, this material reacts with methane to $\gamma$-Fe without any non-stoichiometry, and no peak-shift is observed. The peak shift observed during the oxidation of the $\mathrm{Fe}_{3} \mathrm{O}_{4}$-phase can be explained in similar way. Magnetite $\left(\mathrm{Fe}_{3} \mathrm{O}_{4}\right)$, can have a range of oxidation states dependent upon the amount of $\mathrm{Fe}^{2+}$, which is denoted quantitatively as the magnetite stoichiometry $\left(\chi=\mathrm{Fe}^{\mathrm{II}} / \mathrm{Fe}^{\mathrm{III}}\right)$. Stoichiometric magnetite has a magnetite stoichiometry of $\chi=0.50$. When the material is more oxidized, $\chi$ becomes lower than 0.5 as there is substantially more $\mathrm{Fe}^{\mathrm{III}}$ in the material. When $\chi$ becomes 0 , no $\mathrm{Fe}^{\mathrm{II}}$ is present 
1 in the material and the phase is known as maghemite. The observed peak-shift of the $\mathrm{Fe}_{3} \mathrm{O}_{4-}$ 2 phase to higher values indicates a decrease in lattice parameter which can be explained by the 3 decrease in amount of $\mathrm{Fe}^{\mathrm{II}}$ in the material as $\mathrm{Fe}^{\mathrm{III}}$ is formed. $\mathrm{Fe}_{3} \mathrm{O}_{4}$ will only transform into $4 \mathrm{Fe}_{2} \mathrm{O}_{3}$ when the conversion of $\mathrm{Fe}^{\mathrm{II}}$ to $\mathrm{Fe}^{\mathrm{III}}$ is significantly fulfilled.

Also the $\gamma$-Fe (austenite) lattice parameter changes during reduction and oxidation. During reduction, the lattice parameter stays constant until all $\mathrm{FeO}$ is removed from the oxygen carrier. Afterwards, during the formation of $\mathrm{Fe}_{3} \mathrm{C}$ (cementite), the lattice parameter increases, most likely due to the take-up of $\mathrm{C}$ in octahedral positions in the FCC-lattice. During oxidation, the reverse effect is observed. It is known that several percent of $\mathrm{C}$ can be incorporated in the $\gamma$-Fe lattice, depending on the temperature of the system [49]. During oxidation, only limited $\mathrm{FeO}$ is formed (see Figure 2 and Figure S6 in the supporting information).

\subsection{Active phase - support interactions - detailed investigation}

In our previous work [50], we investigated the interactions between support and active phase. $\mathrm{Fe}$-incorporation into the support lattice occurs especially when $\mathrm{Fe}$ is present as $\mathrm{Fe}^{\mathrm{II}}$. During the subsequent reduction of $\mathrm{Fe}^{\mathrm{II}}$ (in $\mathrm{FeO}$ ) to $\mathrm{Fe}$, the support releases significant amounts of $\mathrm{Fe}$ cations. However, due to the use of ex situ characterization, no systematic take-up and release could be observed as the cations could change their position and further react during coolingdown after the experiment. The formation of $\gamma$-Fe also could not be observed as $\alpha$-Fe is thermodynamically stable below $727^{\circ} \mathrm{C}$ and as the cooling of the oxygen carrier particles was too slow to prevent the phase transition of $\gamma$-Fe to $\alpha$-Fe. These operando experiments however allow us to check in detail how the crystal structure of the spinel support changes and thus where and when $\mathrm{Fe}$ is getting incorporated into the lattice of $\mathrm{MgFeAlO}_{\mathrm{x}}$. For this purpose we investigate several separate XRD-peaks related to this spinel support. These peaks that are located at $Q$ values of $1.32,2.15,3.72$ and $3.95 \AA^{-1}$ are related respectively to the (111), (022), (224) and (115) diffraction planes. For each peak, the area was obtained by integration and these areas are followed through the reduction and oxidation of the oxygen carrier.
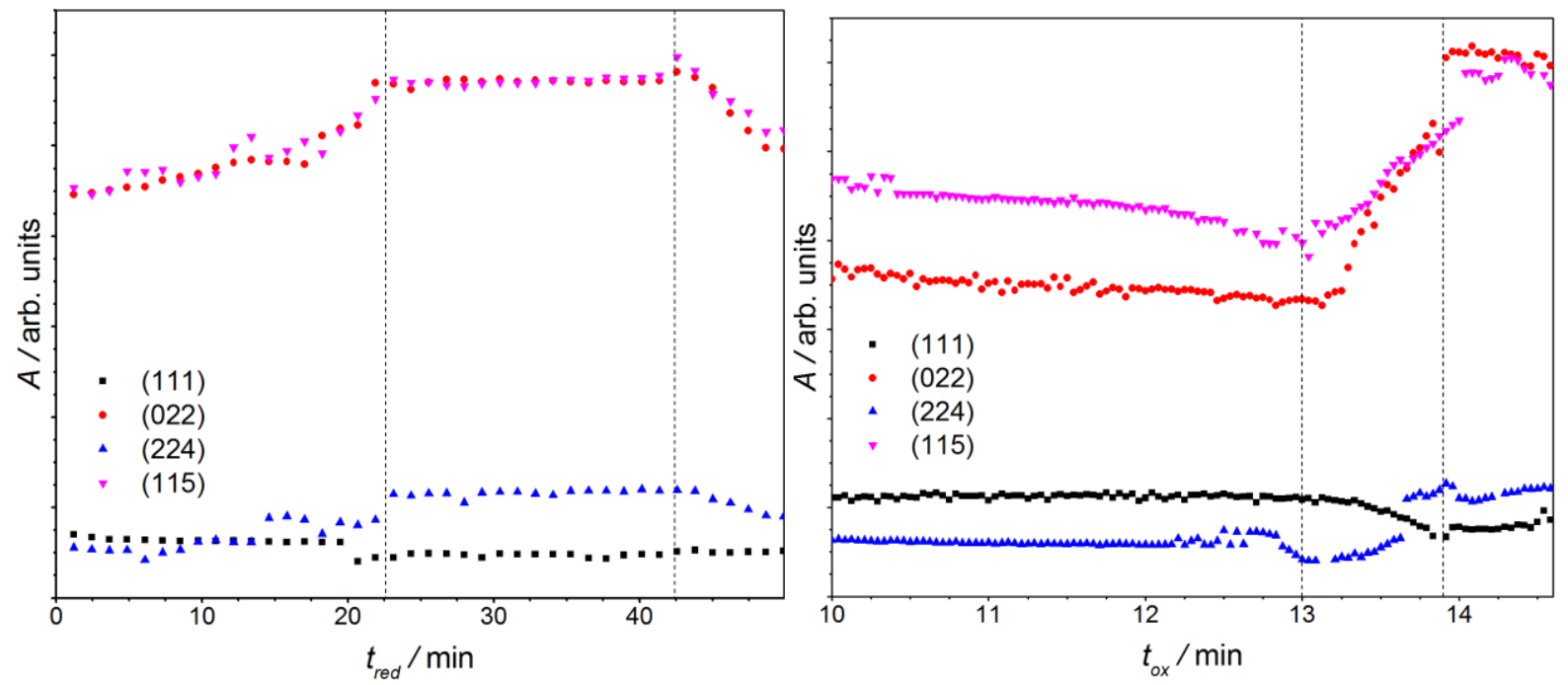

Figure 3: Peak areas related to different XRD diffraction planes of the $\mathrm{MgFeAlO}_{x}$-spinel support calculated from operando measurements during reduction (left) and oxidation (right). Dashed lines indicate times when an active phase is completely converted during oxidation/reduction (linked with Figure 1). 
Figure 3 shows the evolution of these peak areas during the reduction and the oxidation of the oxygen carrier material. It is clearly visible that the phase transformations observed in Figure 2 are directly related to the changes in peak area related to the $\mathrm{MgFeAlO}_{\mathrm{x}}$-spinel. The dashed lines from Figure 3 indicate the times where the respective conversions of $\mathrm{Fe}_{3} \mathrm{O}_{4}$ to $\mathrm{FeO}$ (at 22.6 min reduction time), of $\mathrm{FeO}$ to $\gamma-\mathrm{Fe}$ and $\mathrm{Fe}_{3} \mathrm{C}$ (at $42.5 \mathrm{~min}$ reduction time), of $\mathrm{Fe}_{3} \mathrm{C}$ to $\gamma$ $\mathrm{Fe}$ (at 13 min oxidation time) and of $\gamma-\mathrm{Fe}$ to $\mathrm{FeO}$ and $\mathrm{Fe}_{3} \mathrm{O}_{4}$ (at 13.9 min oxidation time) were completely fulfilled. It is shown that Fe-cations are taken up into the support when $\mathrm{Fe}^{\mathrm{III}}$ is transforming to $\mathrm{Fe}^{\mathrm{II}}$ and that $\mathrm{Fe}$-cations are released during the complete reduction and complete regeneration of the active phase; these observations are in agreement with our previous work [50]. It should however be noted that this experiment was performed in a packedbed setup, with oxygen as oxidizing agent instead of steam and that the material was not yet completely oxidized during the operando measurements at the middle of the reactor bed.

When investigating in more detail the relative changes in peak areas, it can be observed that these areas change systematically. When the peak areas of the (022), (224) and (115) reflections increase (e.g. during the first 22.6 minutes of methane introduction in the oxygen carrier bed), the peak area related to the (111) reflection is decreasing and vice-versa. This systematic change is further observed for the duration of the chemical looping experiment. This systematic change in intensity indicates a systematic take-up and release of Fe-cations at specific positions in the support-lattice as the relative intensities of the support generated diffraction peaks will change depending on the positions of the different cations through the spinel lattice. This is especially true for this material as the atomic scattering factor of $\mathrm{Fe}$ is much larger compared to the atomic scattering factors of $\mathrm{Mg}$ and $\mathrm{Al}$ (in relation with their atomic number). When $\mathrm{Mg}^{\mathrm{II}}$ or $\mathrm{Al}^{\mathrm{III}}$ is replaced with $\mathrm{Fe}^{\mathrm{II}}$ or $\mathrm{Fe}^{\mathrm{III}}$ this affects the intensity of the diffraction peaks. Depending on the take-up at tetratetrahedral or at octahedral positions different relative intensities of the spinel support peaks will be observed. In this regard, the systematic decrease of peaks related to the (111) reflection combined with a systematic increase of peaks related to (022), (224) and (115) reflections is an indication of an increased structure factor at tetrahedral positions. Due to the atomic scattering factor of Fe being higher compared to (similar) atomic scattering factors of $\mathrm{Mg}$ and $\mathrm{Al}$, this increased structure factor at tetrahedral position can only be explained by the take-up of Fe into this position.

The structure factor related to the (111), (022), (224) and (115) planes of a cubic spinel $\mathrm{AB}_{2} \mathrm{O}_{4}$ of the F d $-3 \mathrm{~m} \mathrm{Z}$ space group can be calculated by the following equations:

$$
\begin{aligned}
& \mathrm{F}_{(111)}=-4 \cdot 2^{1 / 2} \cdot \mathrm{f}_{\mathrm{A}}+8 \cdot \mathrm{f}_{\mathrm{B}}+\mathrm{k}_{1} \cdot \mathrm{f}_{\mathrm{O}} \cdot \mathrm{q}(\mathrm{u}) \\
& \mathrm{F}_{(022)}=-8 \cdot \mathrm{f}_{\mathrm{A}}+\mathrm{k}_{2} \cdot \mathrm{f}_{\mathrm{O}} \cdot \mathrm{q}^{\prime}(\mathrm{u}) \\
& \mathrm{F}_{(224)}=8 \cdot \mathrm{f}_{\mathrm{A}}+\mathrm{k}_{3} \cdot \mathrm{f}_{\mathrm{O}} \cdot \mathrm{q}^{\prime}{ }^{\prime}(\mathrm{u}) \\
& \mathrm{F}_{(115)}=4 \cdot 2^{1 / 2} \cdot \mathrm{f}_{\mathrm{A}}+8 \cdot \mathrm{f}_{\mathrm{B}}+\mathrm{k}_{4} \cdot \mathrm{f}_{\mathrm{O}} \cdot \mathrm{q}^{\prime \prime},(\mathrm{u})
\end{aligned}
$$

With $f_{A}, f_{B}$, and $f_{O}$ the atomic scattering factors of atoms at the $A$ and $B$ sites and oxygen respectively, $\mathrm{k}_{\mathrm{i}}$ a constant and $\mathrm{q}(\mathrm{u})$, q'(u), q', $(\mathrm{u})$ and $\mathrm{q}^{\prime \prime \prime}(\mathrm{u})$ functions of the oxygen deformation parameter (which changes depending on the cations in the spinel lattice).

The peak intensity at a certain hkl value is related with the structure factor by equation (5)

$$
\mathrm{I}=|\mathrm{F}|^{2} \cdot \mathrm{c}
$$


1 With c a constant depending on several factors such as the temperature, the absorption factor 2 of the material for X-rays, etc.

3 It is thus indicated that an increase in peak intensity of the (022) and (224) reflections is only 4 influenced by the structure factors of the atoms on the A sites (tetrahedral sites). Because there 5 is no free $\mathrm{Mg}$ or $\mathrm{Al}$ in the oxygen carrier material, no additional spinel can be generated. This 6 increase in peak area can therefore not be attributed to an increase in total amount of spinel, but 7 to an increase of $\mathrm{f}_{\mathrm{A}}$. Because the atomic scattering factor of $\mathrm{Fe}$ is around 2.4 times the atomic 8 scattering factor for $\mathrm{Mg}^{\mathrm{II}}$ and $\mathrm{Al}^{\mathrm{III}}$, this increase shows that $\mathrm{Fe}$-cations are taken up at the $\mathrm{A}$ 9 (tetrahedral) sites. The decrease and increase of the respective peaks related to the (111) and 10 (115) reflections can also only be explained by an increase in $f_{A}$, as a significant increase in $f_{B}$ 11 would also lead to an increase in peak area of the (111) reflection.
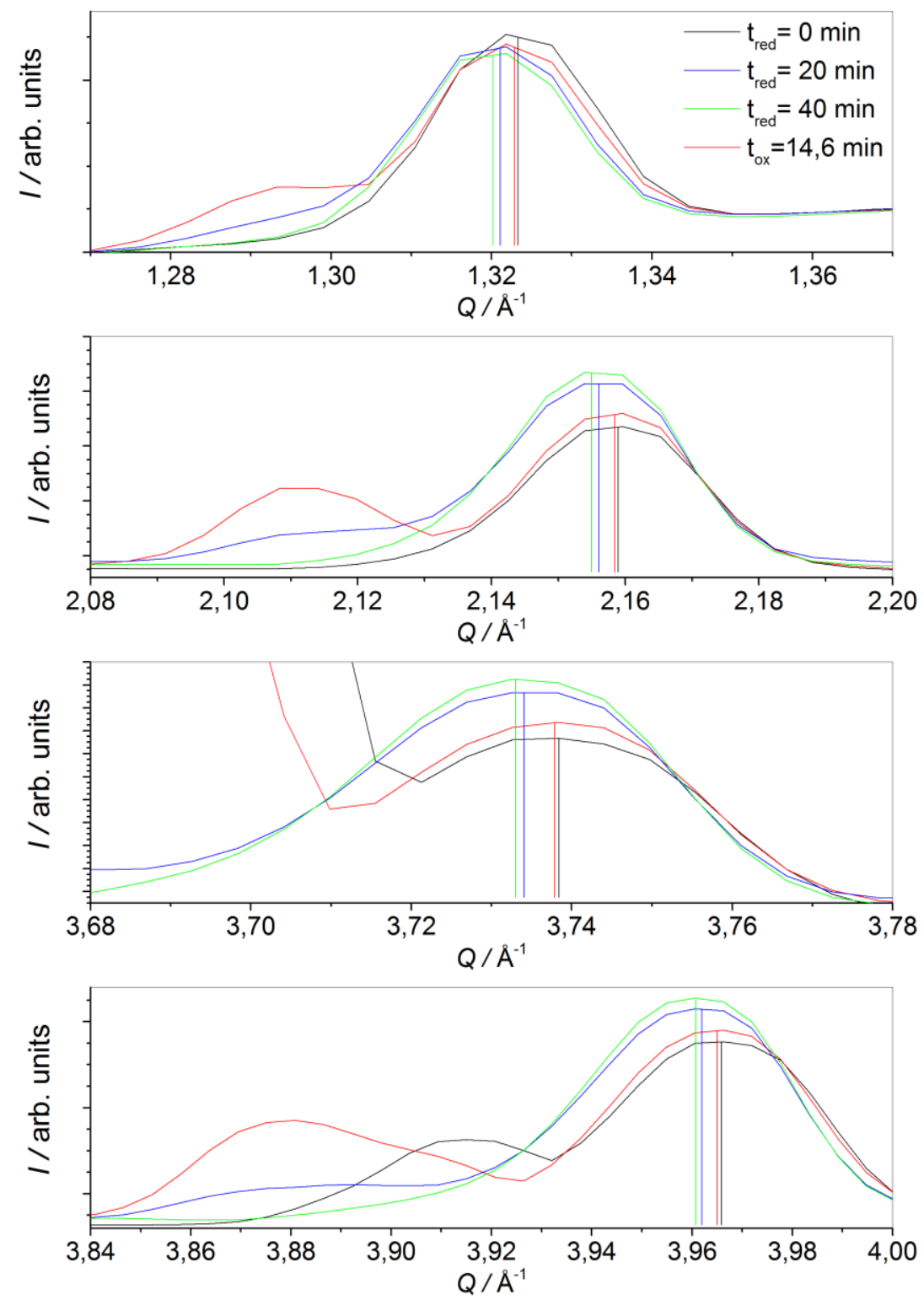

Figure 4: Peak shift of peaks related to the (111), (022), (224) and (115) diffraction planes (from top to bottom) taken from full XRD-scans at position 1 of the bed before reaction, after 20 and 40 minutes of reduction and after oxidation to a mixture of $\mathrm{Fe}_{3} \mathrm{O}_{4}$ and $\mathrm{Fe}_{2} \mathrm{O}_{3}$.

16 The take-up of Fe-cations in the support lattice is also supported by the change in lattice parameter size. During the incorporation of Fe-cations in the support lattice, the size of the unit 
cell increases as Fe-cations are larger compared to $\mathrm{Mg}^{\mathrm{II}}$ and $\mathrm{Al}^{\mathrm{III}}$. This increase in unit cell increases the $\mathrm{d}$-spacing between the planes and thus shifts the peaks towards lower $\mathrm{Q}$ values. This can be observed from the peak shifts shown in Figure 4. During oxidation significant amounts of Fe-cations are released again from the support because the support-peaks shift almost completely back to their position from before reaction. The lattice parameter $a$ of the cubic spinel lattice and the composition of the oxygen carrier determined by Rietveld refinement at certain points during the measurement are included in Table 1. The lattice parameter increases during reduction due to the peak shift to lower Q-values, as shown in Figure 4 and increases during oxidation.

Small changes in the material composition are observed compared to the composition displayed of the same material in previous publications [33,50]. These changes can be explained as these measurements were executed in situ, after heating the material. While the previous publications stated the presence of small amounts of $\mathrm{Al}_{2} \mathrm{O}_{3}(0.7 \%)$ and $\mathrm{MgFe}_{2} \mathrm{O}_{4}(0.9 \%)$ [33,50], these phases were not observed after heating before reaction. The next difference is a slight shift in amounts of spinel support (from $63.5 \%$ to $57.2 \%$ ) and active phase (from $34.9 \%$ to $42.8 \%$ ). Both changes can be explained by heating the material. While the increase in temperature might have facilitated further reaction between $\mathrm{Al}_{2} \mathrm{O}_{3}, \mathrm{MgFe}_{2} \mathrm{O}_{4}$ and the other constituents of the material, this also might have resulted in a slight change in spinel composition and a change in positions of $\mathrm{Fe}, \mathrm{Mg}$ and $\mathrm{Al}$ in its roster (which can be explained by some spinel inversion).

After 40 minutes of reduction, the active material is mostly converted to $\mathrm{FeO}$, while almost $10 \%$ increase in $\mathrm{MgFeAlO}_{\mathrm{x}}$-spinel was observed due to (i) the take-up of Fe-cations in the spinel-lattice and (ii) the release of oxygen from the oxygen carrier. Afterwards, the material was further reduced until all active phase was converted to $\mathrm{Fe}_{3} \mathrm{C}$. After the oxidation under the flow of air for 14.6 minutes almost all iron oxides were converted back to $\mathrm{Fe}_{2} \mathrm{O}_{3}$. The Fe which was incorporated in the spinel support was released back during this oxidation as observed from the peak shift to higher Q-values shown in Figure 4 and the decrease in amount of spinel support shown in Table 1.

Table 1: Lattice parameter of spinel support (a) and composition of the oxygen carrier at the top of the reactor bed at several times during reaction.

\begin{tabular}{lcccccc}
\hline Time & $\mathrm{a} / \AA$ & $\mathrm{MgFeAlO}_{\mathrm{x}} / \%$ & $\alpha-\mathrm{Fe}_{2} \mathrm{O}_{3} \%$ & $\mathrm{Fe}_{3} \mathrm{O}_{4} / \%$ & $\mathrm{FeO} / \%$ & $\gamma-\mathrm{Fe} / \%$ \\
\hline Before reaction & 8.227 & 57.2 & 42.8 & & & \\
20 min red & 8.238 & 60.6 & & 7.8 & 31.6 & \\
40 min red & 8.243 & 67.0 & & & 31.7 & 1.4 \\
14.6 min ox & 8.228 & 55.4 & 29.7 & 14.9 & & \\
\hline
\end{tabular}

31 In summary it is shown that Fe-cations were incorporated and released in/from support during 32 chemical looping operation at tetrahedral position in the spinel lattice. Both during reduction 33 from $\mathrm{Fe}^{\mathrm{III}}$ to $\mathrm{Fe}^{\mathrm{II}}$ and during oxidation of $\mathrm{Fe}^{0}$ to $\mathrm{Fe}^{\mathrm{II}}$, the $\mathrm{Fe}$-cations were incorporated into the 34 spinel lattice. These Fe-cations were released afterwards during respective transformations of $35 \mathrm{Fe}^{\mathrm{II}}$ to $\mathrm{Fe}^{0}$ and of $\mathrm{Fe}^{\mathrm{II}}$ to $\mathrm{Fe}^{\mathrm{III}}$. Also in the presence of $\mathrm{Fe}_{3} \mathrm{C}$ during the oxidation a slow release 36 of Fe-cations was observed. Only minor amounts of $\mathrm{Fe}$-cations are incorporated in the spinel 37 lattice leading to an increased amount of spinel support from $57.2 \%$ to $67 \%$ at 40 minutes of 
1 reduction and a significant oxygen transport is still available for reaction as a significant amount

2 of active phase is still present in the material.

\section{$3 \quad 3.3$ XRD-CT at bottom of the reactor bed}

4 At certain moments during operation the reactive gas flow was stopped and changed to He and 5 several XRD-CT-scans were taken at three bed heights in order to capture the spatial 6 distribution of the XRD-signals. With these tomographic diffraction measurements, it was 7 possible to investigate the spatial distribution of the various crystalline components present in 8 the oxygen carrier.

9 Figure 5 and Figure 6 different XRD-CT images extracted from scans performed at position 3 10 inside the oxygen carrier bed at several moments during operation. It is possible to see the 11 spatial distribution of the different phases throughout the oxygen carrier bed Figure 5. Also the 12 change in intensity through chemical looping operation can be investigated, which is especially 13 important for the interactions between spinel support and active phase. In order to mitigate the 14 effect of aforementioned peak shifts on the intensities shown in Figure 5 peak areas were 15 calculated instead.

16 In Figure 5, it is shown that the active phase inside the oxygen carrier bed is transforming from $17 \mathrm{Fe}_{2} \mathrm{O}_{3}$ before reaction to $\mathrm{FeO}$ and a minor amount of $\mathrm{Fe}_{3} \mathrm{O}_{4}$ after 20 minutes of reduction, and 18 to $\mathrm{FeO}$ and minor amounts of $\gamma$-Fe after 40 minutes of reduction. After oxidation the material 19 is partially oxidized back to $\mathrm{Fe}_{2} \mathrm{O}_{3}$ and $\mathrm{Fe}_{3} \mathrm{O}_{4}$. It is visible that the reactive front propagation is 20 not completely homogeneous in the radial direction of the reactor, but only minor differences 21 can be observed. 


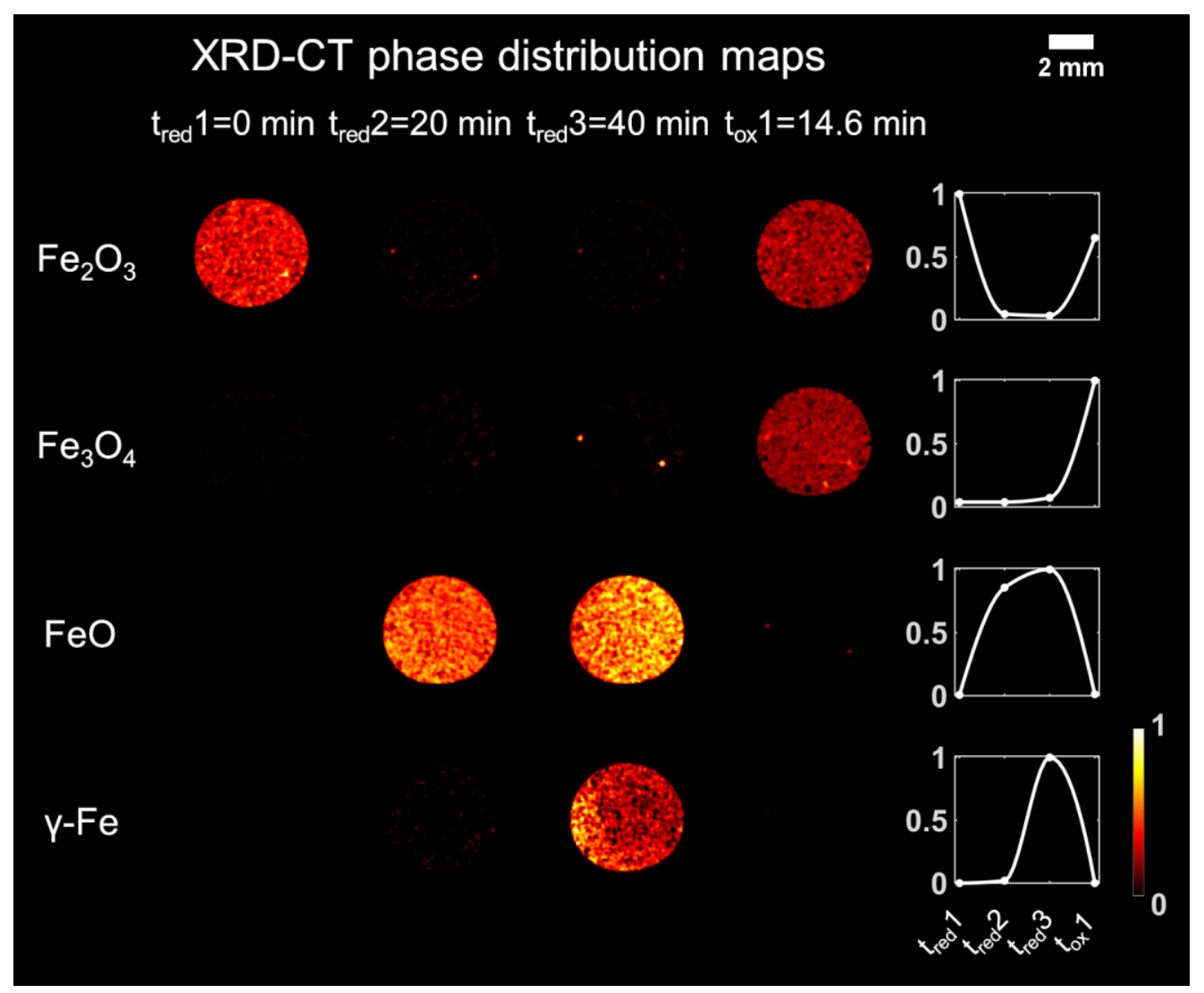

Figure 5: Set of four XRD-CT slices taken from position 3 inside the OC bed. From left to right, each column displays a different time during operation; before reaction, after 20 minutes of reduction, after 40 minutes of reduction and after (partial) oxidation. From top to bottom the different active phases are displayed. The used intensity gradient is included at the bottom-right in the figure. The intensity of each pixel/spot is linearly related to the peak-area, with complete darkness as background value, and maximal intensity as the maximum peak area of the used diffraction peak determined by fitting the peaks with a pseudo-Voigt peak shape function. The changes in relative intensities across the whole slice of the phase is displayed at the right of the figure. 


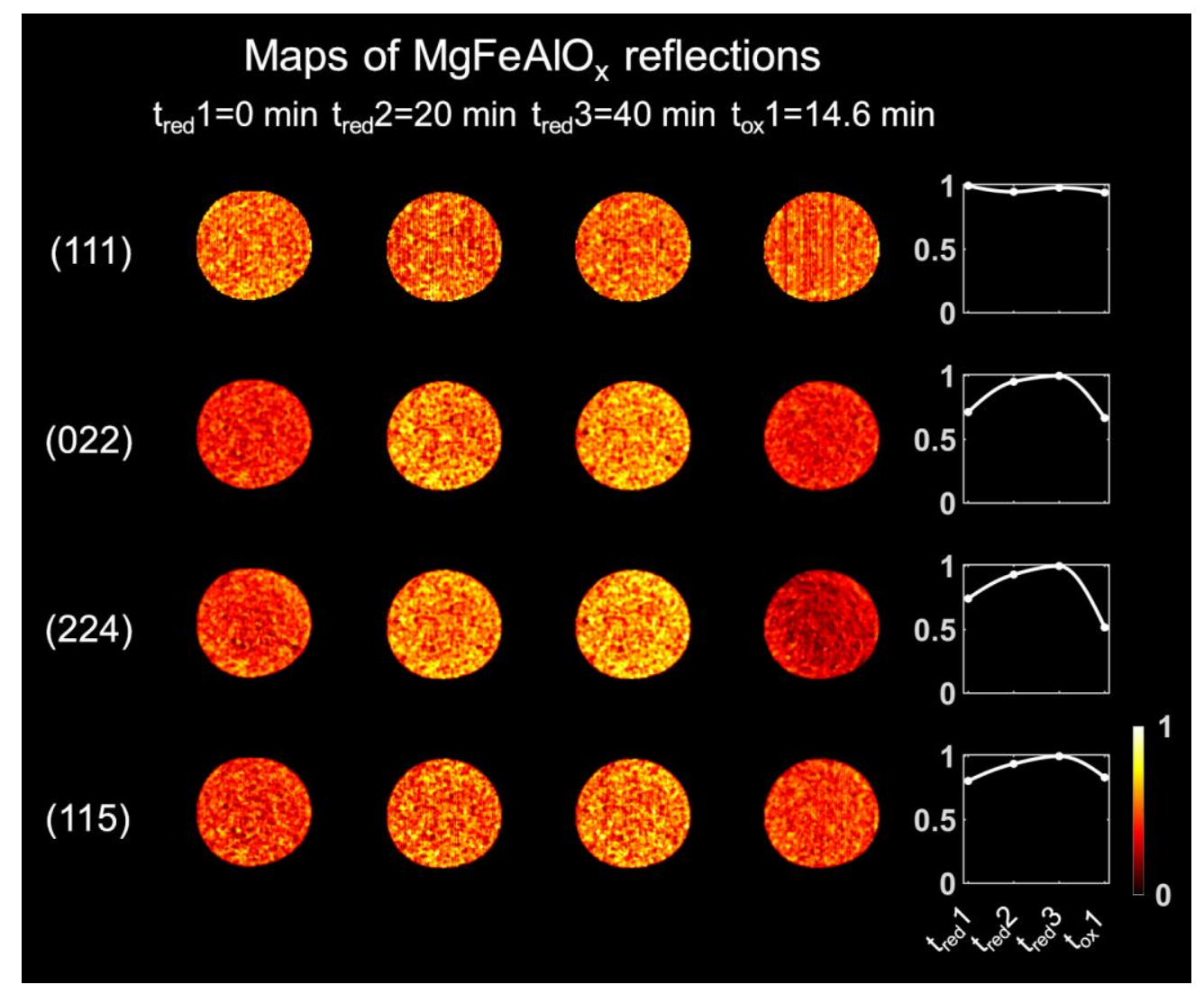

Figure 6: Set of four XRD-CT slices taken from position 3 inside the OC bed. From left to right, each column displays a different time during operation; before reaction, after 20 minutes of reduction, after 40 minutes of reduction and after (partial) oxidation. From top to bottom different important reflections from the $\mathrm{MgFeAlO}_{x}$ are displayed. The used intensity gradient is included at the bottom-right in the figure. The intensity of each pixel/spot is linearly related to the peak-area, with complete darkness as background value, and maximal intensity as the maximum peak area of the used diffraction peak determined by fitting the peaks with a pseudoVoigt peak shape function. The changes in relative intensities across the whole slice of the phase is displayed at the right of the figure.

Also the four previously investigated spinel peaks are investigated by XRD-CT (Figure 6). During the operando point in time measurements during oxidation of the oxygen carrier, the XRD-scans were taken at position 2. Because of the gradient of reactive phases through the bed, the active phase and support at this position were not as oxidized as at position 3 . Therefore we could not yet completely prove that the regeneration of the oxygen carrier results in the release of Fe from the support. By investigating the peaks at the lowest, most oxidized position, a significant release of $\mathrm{Fe}$ from the support can be observed after regeneration.

When comparing the intensities of the peaks related to the (022), (224) and (115) peaks it is shown again that the spinel peaks increase in intensity during reduction up to 40 minutes, when $\mathrm{FeO}$ is significantly present in the bed. At the same time the intensity of the peak related to the (111) phase slightly drops. This trend indicates the take-up of Fe into tetrahedral position of the spinel lattice, as was explained in the previous section. The reverse effect is observed during oxidation/regeneration. The final intensities observed after oxidation to a mixture of 
$1 \mathrm{Fe}_{2} \mathrm{O}_{3} / \mathrm{Fe}_{3} \mathrm{O}_{4}$ are of similar magnitude compared to the intensities before reaction thus

2 indicating a significant regeneration of Fe-cations from the spinel lattice.

\section{$3 \quad 3.4 \quad$ Oxygen carrier microstructure after reaction}

4 After the synchrotron experiment, the packed bed was embedded in an epoxy resin and the microstructure of the oxygen carriers in the packed bed was investigated. During oxidation it was ensured that oxygen was introduced into the reactor only for a limited time to ensure a partial reduction of the oxygen carrier bed. At the bottom of the bed the oxygen carrier should therefore be significantly oxidized to $\mathrm{Fe}_{2} \mathrm{O}_{3} / \mathrm{Fe}_{3} \mathrm{O}_{4}$, while at the top of the bed, the oxygen carrier should still be reduced as Fe/Fe3C. By SEM-EDS the microstructure of the oxygen carriers in the bed was investigated. Figure 7 displays a polished cross-section of the complete embedded oxygen carrier bed. The different phase transitions, visible at higher magnifications, are indicated by white lines along the axis of the packed bed. While the material was significantly oxidized at the bottom, where oxygen was introduced into the reactor, the active phase was still completely reduced at the top. The detailed microstructure at the indicated spots in Figure 7 is shown in Figure 8.

Especially important is the presence of cracks at the bottom of the bed, where the active phase was completely oxidized to $\mathrm{Fe}_{2} \mathrm{O}_{3}$. It is not possible to completely explain the origin of these cracks because numerous factors should be assessed. They could be due to the weight of the packed bed, the pressure drop across the bed, the fast cooling and heating rates or even due to the phase transitions of the active phase, as each phase has its molar volume which can be different depending on the temperature and the expansion coefficient of the respective phases. It should however be noted that $\mathrm{H}_{2} \mathrm{O}$ oxidation of this oxygen carrier material in both packed bed as fluidized bed reactors did not result in cracks (see Figure S8 in supporting information for cross sections of embedded OC material after 20 cycles of steam/methane chemical looping executed in experiments from previous publications [33,50]). During steam-oxidation, the maximum thermodynamically attainable oxidation state of the active phase is $\mathrm{Fe}_{3} \mathrm{O}_{4}$. 


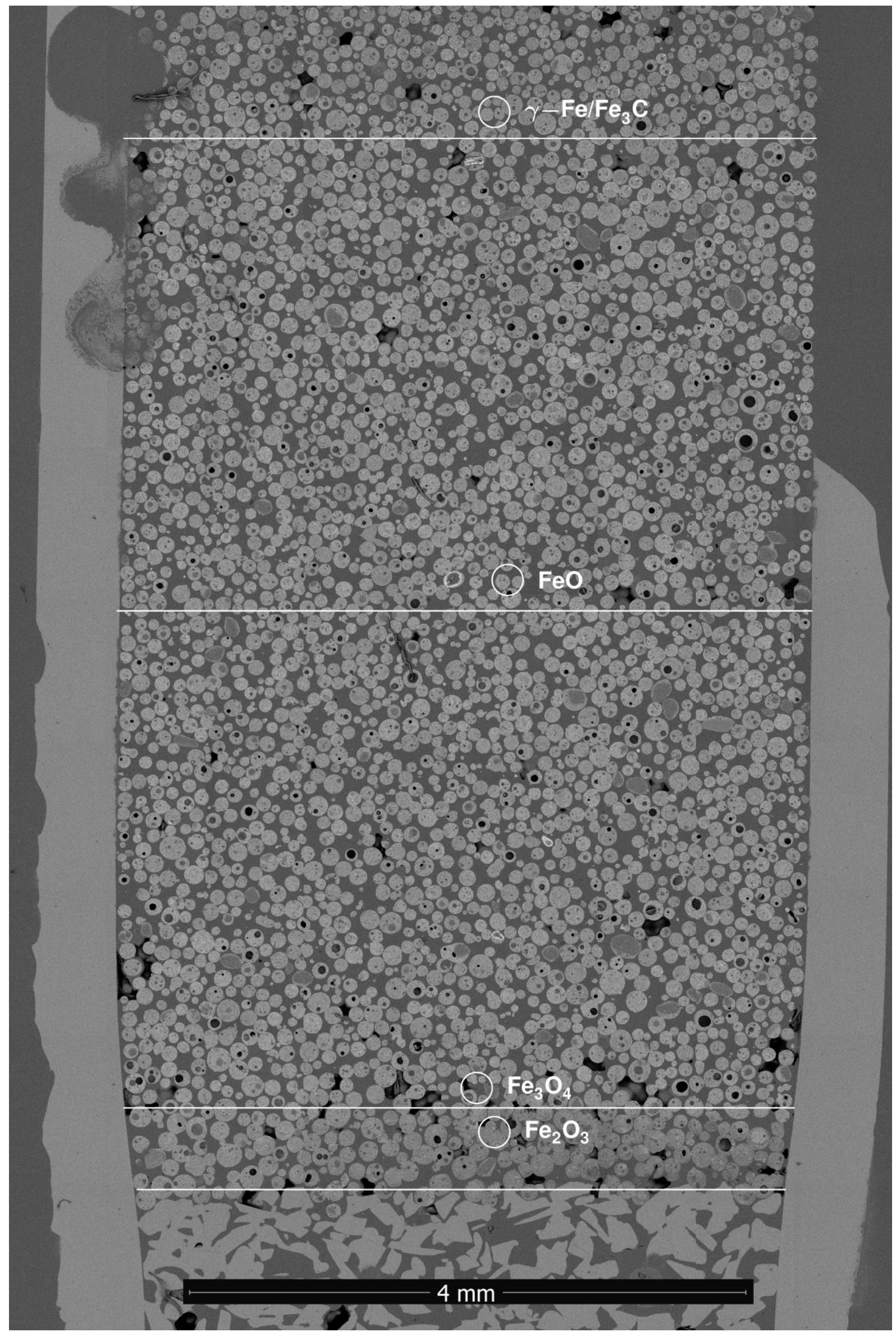

Figure 7: Embedded oxygen carrier bed by SEM after synchrotron experiment. Locations of microstructure images in Figure 7 are denoted with white circles. White lines represent visible transitions in microstructure. 


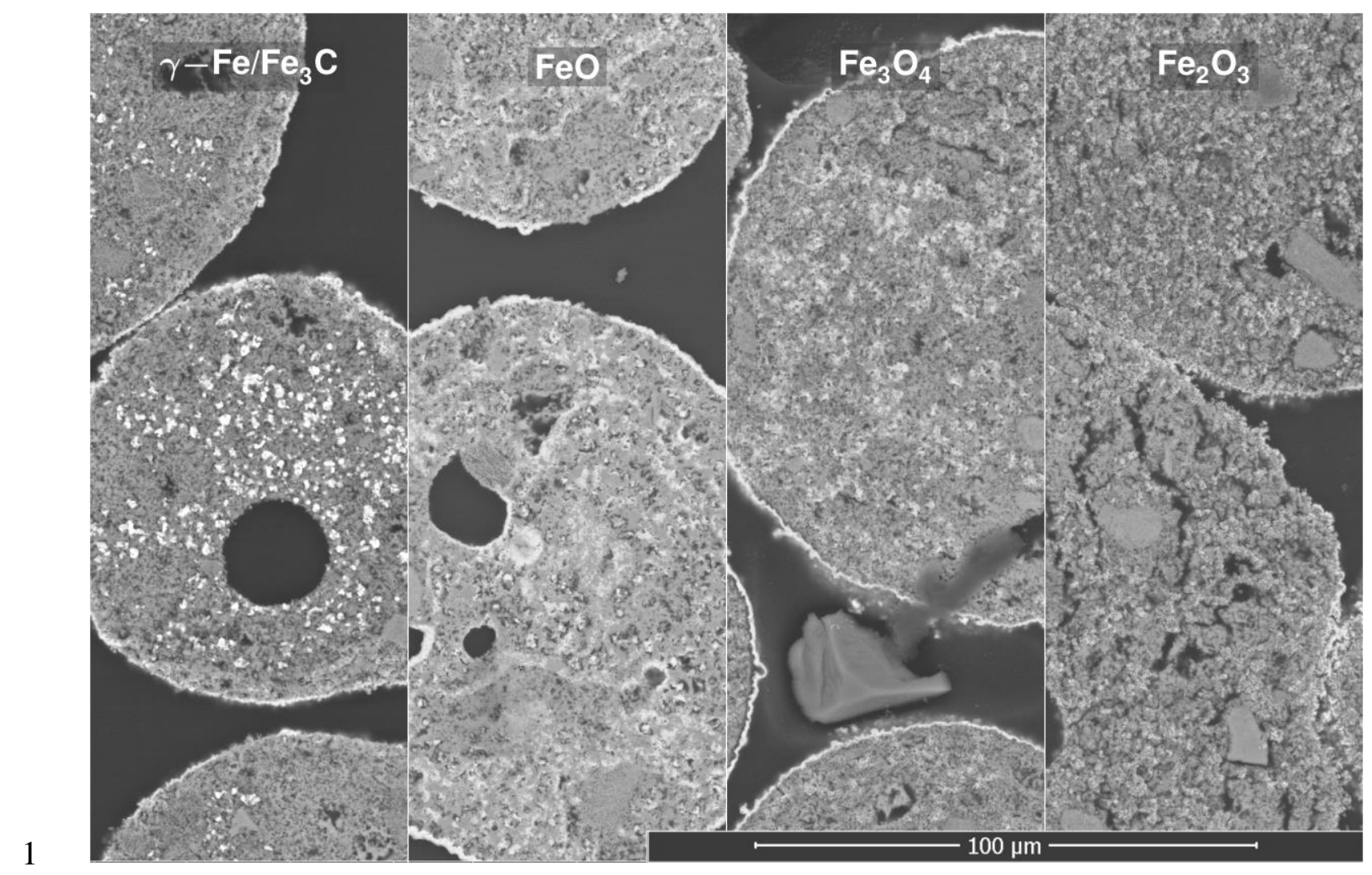

Figure 8: Microstructure of selected oxygen carriers inside embedded reactor bed after synchrotron experiment by SEM.

\section{Conclusions}

Spray dried $\mathrm{Mg}_{1-\mathrm{x}} \mathrm{Al}_{2-\mathrm{y}} \mathrm{Fe}_{\mathrm{x}+\mathrm{y}} \mathrm{O}_{4}$-supported oxygen carriers were investigated during methane reduction and oxygen oxidation at $900^{\circ} \mathrm{C}$ using a packed-bed reactor test coupled with operando XRD measurements utilizing synchrotron radiation. During operation, the reactive gas flows were switched several times to He and in situ XRD-CT scans were taken to gain a better understanding of the relationship between the spatial distribution of the phases (both radial and axial at several positions across the oxygen carrier bed) and time.

11 The $\mathrm{Mg}_{1-\mathrm{x}} \mathrm{Al}_{2-\mathrm{y}} \mathrm{Fe}_{\mathrm{x}+\mathrm{y}} \mathrm{O}_{4^{-}}$(denoted $\mathrm{MgFe} \mathrm{AlO}_{\mathrm{x}}$ in this paper) supported oxygen carrier displayed sequential reactions from $\mathrm{Fe}_{2} \mathrm{O}_{3}$ to $\mathrm{Fe}_{3} \mathrm{C}$ during reduction. During oxidation at $900^{\circ} \mathrm{C}$, only minor amounts of $\mathrm{FeO}$ were present as the $\gamma$-Fe was almost readily oxidized to $\mathrm{Fe}_{3} \mathrm{O}_{4}$.

14 Under chemical looping operation conditions, it was shown that Fe-cations were incorporated and released in/from the support at a tetrahedral position in the spinel lattice. Both during reduction from $\mathrm{Fe}^{\mathrm{III}}$ to $\mathrm{Fe}^{\mathrm{II}}$ and during oxidation of $\mathrm{Fe}^{0}$ to $\mathrm{Fe}^{\mathrm{II}}$, the $\mathrm{Fe}$-cations were incorporated into the spinel lattice. These Fe-cations were released afterwards during respective transformations of $\mathrm{Fe}^{\mathrm{II}}$ to $\mathrm{Fe}^{0}$ and of $\mathrm{Fe}^{\mathrm{II}}$ to $\mathrm{Fe}^{\mathrm{III}}$. Also, in the presence of $\mathrm{Fe}_{3} \mathrm{C}$ during the oxidation, a slow release of Fe-cations was observed. In the end it was displayed that only minor amounts of Fe were incorporated in the spinel lattice and that a significant oxygen transport is still available for reaction

The microstructure of the oxygen carriers in the packed bed was investigated ex situ after reaction by SEM and it was shown that cracks appeared when the oxygen carrier was fully 
1 oxidized to $\mathrm{Fe}_{2} \mathrm{O}_{3}$. The origin of these cracks was not yet completely determined but it should

2 be noted that oxidation to $\mathrm{Fe}_{3} \mathrm{O}_{4}$, which is present as the most oxidized phase possible when

3 regenerating with $\mathrm{H}_{2} \mathrm{O}$, does not pose any problems.

\section{Acknowledgements}

This work was supported by the FWO-Vlaanderen (Fund for Scientific Research) [grant number $1 \mathrm{~S} 16516 \mathrm{~N}]$.

The authors would like to thank the ESRF for beamtime and the staff of ID15A beamline, in particular Marco Di Michiel, for assistance with the set up and data collection.

Y. De Vos also thanks R. Kemps, M. Mertens, A.M. De Wilde, M. Gysen, D. Vanhoyweghen, and P. Lens at VITO for their technical support.

\section{References}

[1] Zheng, Y., Li, K., Wang, H., Tian, D., Wang, Y., Zhu, X. et al. (2017) Designed oxygen carriers from macroporous $\mathrm{LaFeO} 3$ supported $\mathrm{CeO} 2$ for chemical-looping reforming of methane. Applied Catalysis B: Environmental, 202, 51-63. https://doi.org/10.1016/j.apcatb.2016.08.024

[2] Stroud, T., Smith, T.J., Le Saché, E., Santos, J.L., Centeno, M.A., Arellano-Garcia, H. et al. (2018) Chemical CO 2 recycling via dry and bi reforming of methane using Ni-Sn/Al 2 O 3 and Ni-Sn/CeO 2 -Al 2 O 3 catalysts. Applied Catalysis B: Environmental, 224, 12535. https://doi.org/10.1016/j.apcatb.2017.10.047

[3] Hossain, M.M. and de Lasa, H.I. (2008) Chemical-looping combustion (CLC) for inherent CO2 separations-a review. Chemical Engineering Science, 63, 4433-51. https://doi.org/10.1016/j.ces.2008.05.028

[4] Spallina, V., Gallucci, F., Romano, M.C., Chiesa, P., Lozza, G. and van Sint Annaland, M. (2013) Investigation of heat management for CLC of syngas in packed bed reactors. Chemical Engineering Journal, 225, 174-91. https://doi.org/10.1016/j.cej.2013.03.054

[5] Mancuso, L., Cloete, S., Chiesa, P. and Amini, S. (2017) Economic assessment of packed bed chemical looping combustion and suitable benchmarks. International Journal of Greenhouse Gas Control, 64, 223-33. https://doi.org/10.1016/j.ijggc.2017.07.015

[6] Ortiz, M., Gallucci, F., Snijkers, F., Van Noyen, J., Louradour, E., Tournigant, D. et al. (2014) Development and testing of ilmenite granules for packed bed chemical-looping combustion. Chemical Engineering Journal, 245, 228-40. https://doi.org/10.1016/j.cej.2014.02.030

[7] Jacobs, M., Van Noyen, J., Larring, Y., Mccann, M., Pishahang, M., Amini, S. et al. (2015) Thermal and mechanical behaviour of oxygen carrier materials for chemical looping combustion in a packed bed reactor. Applied Energy, 157, 374-81. https://doi.org/10.1016/j.apenergy.2015.04.053

[8] Hamers, H.P., Gallucci, F., Cobden, P.D., Kimball, E. and van Sint Annaland, M. (2013) A novel reactor configuration for packed bed chemical-looping combustion of syngas. International Journal of Greenhouse Gas Control, 16, 1-12. https://doi.org/10.1016/j.ijggc.2013.02.021 
[9] Hamers, H.P., Romano, M.C., Spallina, V., Chiesa, P., Gallucci, F. and Annaland, M. van S. (2014) Comparison on process efficiency for CLC of syngas operated in packed bed and fluidized bed reactors. International Journal of Greenhouse Gas Control, 28, 65-78. https://doi.org/10.1016/j.ijggc.2014.06.007

[10] Hamers, H.P., Gallucci, F., Cobden, P.D., Kimball, E. and van Sint Annaland, M. (2014) CLC in packed beds using syngas and $\mathrm{CuO} / \mathrm{Al} 2 \mathrm{O} 3$ : Model description and experimental validation. Applied Energy, 119, 163-72. https://doi.org/10.1016/j.apenergy.2013.12.053

[11] Spallina, V., Marinello, B., Gallucci, F., Romano, M.C. and Van Sint Annaland, M. (2017) Chemical looping reforming in packed-bed reactors: Modelling, experimental validation and large-scale reactor design. Fuel Processing Technology, 156, 156-70. https://doi.org/10.1016/j.fuproc.2016.10.014

[12] Adanez, J., Abad, A., Garcia-Labiano, F., Gayán, P. and de Diego, L.F. (2012) Progress in Chemical-Looping Combustion and Reforming technologies. Progress in Energy and Combustion Science, 38, 215-82. https://doi.org/10.1016/j.pecs.2011.09.001

[13] Kathe, M.V., Empfield, A., Na, J., Blair, E. and Fan, L.-S. (2016) Hydrogen production from natural gas using an iron-based chemical looping technology: Thermodynamic simulations and process system analysis. Applied Energy, 165, 183-201. https://doi.org/10.1016/j.apenergy.2015.11.047

[14] Protasova, L. and Snijkers, F. (2016) Recent developments in oxygen carrier materials for hydrogen production via chemical looping processes. Fuel, 181, 75-93. https://doi.org/10.1016/j.fuel.2016.04.110

[15] Tang, M., Xu, L. and Fan, M. (2015) Progress in oxygen carrier development of methane-based chemical-looping reforming: A review. Applied Energy, 151, 143-56. https://doi.org/10.1016/j.apenergy.2015.04.017

[16] Bhavsar, S., Isenberg, N., More, A. and Veser, G. (2016) Lanthana-doped ceria as active support for oxygen carriers in chemical looping combustion. Applied Energy, 168, 236-47. https://doi.org/10.1016/j.apenergy.2016.01.073

[17] Ma, S., Li, M., Wang, G., Zhang, L., Chen, S., Sun, Z. et al. (2018) Effects of Zr doping on $\mathrm{Fe} 2 \mathrm{O} 3 / \mathrm{CeO} 2$ oxygen carrier in chemical looping hydrogen generation. Chemical Engineering Journal, 346, 712-25. https://doi.org/10.1016/j.cej.2018.03.171

[18] Ma, S., Chen, S., Soomro, A., Zhu, M. and Xiang, W. (2018) Characterization of Fe 2 O $3 / \mathrm{CeO} 2$ oxygen carriers for chemical looping hydrogen generation. International Journal of Hydrogen Energy, 43, 3154-64. https://doi.org/10.1016/j.ijhydene.2017.12.111

[19] Kang, D., Lee, M., Lim, H.S. and Lee, J.W. (2018) Chemical looping partial oxidation of methane with $\mathrm{CO} 2$ utilization on the ceria-enhanced mesoporous Fe $2 \mathrm{O} 3$ oxygen carrier. Fuel, 215, 787-98. https://doi.org/10.1016/j.fuel.2017.11.106

[20] Dueso, C., Thompson, C. and Metcalfe, I. (2015) High-stability, high-capacity oxygen carriers: Iron oxide-perovskite composite materials for hydrogen production by chemical looping. Applied Energy, 157, 382-90. https://doi.org/10.1016/j.apenergy.2015.05.062 
[21] Galinsky, N.L., Shafiefarhood, A., Chen, Y., Neal, L. and Li, F. (2015) Effect of support on redox stability of iron oxide for chemical looping conversion of methane. Applied Catalysis B: Environmental, 164, 371-9. https://doi.org/10.1016/j.apcatb.2014.09.023

[22] Chen, Y., Galinsky, N., Wang, Z. and Li, F. (2014) Investigation of perovskite supported composite oxides for chemical looping conversion of syngas. Fuel, 134, 521-30. https://doi.org/10.1016/j.fuel.2014.06.017

[23] Fernández, J.R., Abanades, J.C., Murillo, R. and Grasa, G. (2012) Conceptual design of a hydrogen production process from natural gas with $\mathrm{CO} 2$ capture using a $\mathrm{Ca}-\mathrm{Cu}$ chemical loop. International Journal of Greenhouse Gas Control, 6, 126-41. https://doi.org/10.1016/j.ijggc.2011.11.014

[24] Kuusik, R., Trikkel, A., Lyngfelt, A. and Mattisson, T. (2009) High temperature behavior of NiO-based oxygen carriers for Chemical Looping Combustion. Energy Procedia, 1, 3885-92. https://doi.org/10.1016/j.egypro.2009.02.191

[25] Gayán, P., de Diego, L.F., García-Labiano, F., Adánez, J., Abad, A. and Dueso, C. (2008) Effect of support on reactivity and selectivity of Ni-based oxygen carriers for $\begin{array}{llll}\text { chemical-looping } & \text { combustion. } & \text { Fuel, } & \text { 87, }\end{array}$ https://doi.org/10.1016/j.fuel.2008.02.016

[26] Arjmand, M., Azad, A.-M., Leion, H., Lyngfelt, A. and Mattisson, T. (2011) Prospects of $\mathrm{Al}_{2} \mathrm{O}_{3}$ and $\mathrm{MgAl}_{2} \mathrm{O}_{4}$-Supported $\mathrm{CuO}$ Oxygen Carriers in Chemical-Looping Combustion (CLC) and Chemical-Looping with Oxygen Uncoupling (CLOU). Energy \& Fuels, 25, 5493-502. https://doi.org/10.1021/ef201329x

[27] Imtiaz, Q., Broda, M. and Müller, C.R. (2014) Structure-property relationship of coprecipitated $\mathrm{Cu}$-rich, $\mathrm{Al} 2 \mathrm{O} 3$ - or $\mathrm{MgAl} 2 \mathrm{O} 4$-stabilized oxygen carriers for chemical looping with oxygen uncoupling (CLOU). Applied Energy, 119, 557-65. https://doi.org/10.1016/j.apenergy.2014.01.007

[28] Imtiaz, Q., Kurlov, A., Rupp, J.S. and Müller, C.R. (2015) Highly Efficient OxygenStorage Material with Intrinsic Coke Resistance for Chemical Looping Combustion-Based CO2 Capture. ChemSusChem, 8, 2055-65. https://doi.org/10.1002/cssc.201403426

[29] Luo, M., Wang, S., Wang, L. and Lv, M. (2014) Reduction kinetics of iron-based oxygen carriers using methane for chemical-looping combustion. Journal of Power Sources, 270, 434-40. https://doi.org/10.1016/j.jpowsour.2014.07.100

[30] Leion, H., Mattisson, T. and Lyngfelt, A. (2007) The use of petroleum coke as fuel in chemical-looping combustion. $\quad$ Fuel, $\quad \mathbf{8 6}, \quad$ 1947-58. https://doi.org/10.1016/j.fuel.2006.11.037

[31] Leion, H., Mattisson, T. and Lyngfelt, A. (2008) Solid fuels in chemical-looping combustion. International Journal of Greenhouse Gas Control, 2, 180-93. https://doi.org/10.1016/S1750-5836(07)00117-X

[32] Rydén, M. and Arjmand, M. (2012) Continuous hydrogen production via the steamiron reaction by chemical looping in a circulating fluidized-bed reactor. International Journal of Hydrogen Energy, 37, 4843-54. https://doi.org/10.1016/j.ijhydene.2011.12.037 
[33] De Vos, Y., Jacobs, M., Van Driessche, I., Van Der Voort, P., Snijkers, F. and Verberckmoes, A. (2018) Processing and characterization of Fe-based oxygen carriers for chemical looping for hydrogen production. International Journal of Greenhouse Gas Control, 70, 12-21. https://doi.org/10.1016/j.ijggc.2018.01.007

[34] Hafizi, A., Rahimpour, M.R. and Hassanajili, Sh. (2016) Hydrogen production via chemical looping steam methane reforming process: Effect of cerium and calcium promoters on the performance of Fe2O3/Al2O3 oxygen carrier. Applied Energy, 165, 68594. https://doi.org/10.1016/j.apenergy.2015.12.100

[35] Hu, J., Galvita, V.V., Poelman, H., Detavernier, C. and Marin, G.B. (2018) Catalystassisted chemical looping auto-thermal dry reforming: Spatial structuring effects on process efficiency. Applied Catalysis B: Environmental, 231, 123-36. https://doi.org/10.1016/j.apcatb.2018.03.004

[36] Hu, J., Buelens, L., Theofanidis, S.-A., Galvita, V.V., Poelman, H. and Marin, G.B. (2016) CO2 conversion to CO by auto-thermal catalyst-assisted chemical looping. Journal of CO2 Utilization, 16, 8-16. https://doi.org/10.1016/j.jcou.2016.05.006

[37] Galvita, V.V., Poelman, H. and Marin, G.B. (2011) Hydrogen Production from Methane and Carbon Dioxide by Catalyst-Assisted Chemical Looping. Topics in Catalysis, 54, 90713. https://doi.org/10.1007/s11244-011-9709-7

[38] Galvita, V.V., Poelman, H., Detavernier, C. and Marin, G.B. (2015) Catalyst-assisted chemical looping for CO 2 conversion to CO. Applied Catalysis B: Environmental, 164, 184-91. https://doi.org/10.1016/j.apcatb.2014.09.007

[39] Dharanipragada, N.V.R.A., Buelens, L.C., Poelman, H., De Grave, E., Galvita, V.V. and Marin, G.B. (2015) $\mathrm{Mg}-\mathrm{Fe}-\mathrm{Al}-\mathrm{O}$ for advanced $\mathrm{CO} 2$ to $\mathrm{CO}$ conversion: carbon monoxide yield vs. oxygen storage capacity. Journal of Materials Chemistry A, 3, 1625162. https://doi.org/10.1039/C5TA02289D

[40] Buelens, L.C., Dharanipragada, N.V.R.A., Poelman, H., Zhou, Z., Marin, G.B. and Galvita, V.V. (2019) Exploring the stability of Fe2O3-MgAl2O4 oxygen storage materials for $\mathrm{CO}$ production from CO2. Journal of CO2 Utilization, 29, 36-45. https://doi.org/10.1016/j.jcou.2018.11.008

[41] Theofanidis, S.A., Galvita, V.V., Poelman, H., Dharanipragada, N.V.R.A., Longo, A., Meledina, M. et al. (2018) Fe-Containing Magnesium Aluminate Support for Stability and Carbon Control during Methane Reforming. ACS Catal, 8, 5983-95.

[42] Theofanidis, S.A., Galvita, V.V., Sabbe, M., Poelman, H., Detavernier, C. and Marin, G.B. (2017) Controlling the stability of a Fe-Ni reforming catalyst: Structural organization of the active components. Applied Catalysis B: Environmental, 209, 405-16. https://doi.org/10.1016/j.apcatb.2017.03.025

[43] Vamvakeros, A., Jacques, S.D.M., Di Michiel, M., Matras, D., Middelkoop, V., Ismagilov, I.Z. et al. (2018) 5D operando tomographic diffraction imaging of a catalyst bed. Nature Communications, 9. https://doi.org/10.1038/s41467-018-07046-8

[44] Matras, D., Jacques, S.D.M., Poulston, S., Grosjean, N., Estruch Bosch, C., Rollins, B. et al. (2019) Operando and Postreaction Diffraction Imaging of the $\mathrm{La}-\mathrm{Sr} / \mathrm{CaO}$ Catalyst in 
the Oxidative Coupling of Methane Reaction. The Journal of Physical Chemistry C, 123, 1751-60. https://doi.org/10.1021/acs.jpcc.8b09018

[45] Harding, G., Kosanetzky, J. and Neitzel, U. (1987) X-ray diffraction computed tomography: X-ray diffraction computed tomography. Medical Physics, 14, 515-25. https://doi.org/10.1118/1.596063

[46] De Vos, Y., Jacobs, M., Van Der Voort, P., Van Driessche, I., Snijkers, F. and Verberckmoes, A. (2017) Optimization of spray dried attrition-resistant iron based oxygen carriers for chemical looping reforming. Chemical Engineering Journal, 309, 824-39. https://doi.org/10.1016/j.cej.2016.10.092

[47] Ashiotis, G., Deschildre, A., Nawaz, Z., Wright, J.P., Karkoulis, D., Picca, F.E. et al. (2015) The fast azimuthal integration Python library: pyFAI. Journal of Applied Crystallography, 48, 510-9. https://doi.org/10.1107/S1600576715004306

[48] Vamvakeros, A., Jacques, S.D.M., Di Michiel, M., Middelkoop, V., Egan, C.K., Cernik, R.J. et al. (2015) Removing multiple outliers and single-crystal artefacts from X-ray diffraction computed tomography data. Journal of Applied Crystallography, 48, 1943-55. https://doi.org/10.1107/S1600576715020701

[49] Pero-Sanz Elorz, J.A., Quintana Hernández, M.J. and Verdeja González, L.F. (2017) Solid-State Transformations in the Fe-C System. Solidification and Solid-State Transformations of Metals and Alloys, Elsevier. p. 255-324. https://doi.org/10.1016/B9780-12-812607-3.00008-5

[50] De Vos, Y., Jacobs, M., Van Der Voort, P., Van Driessche, I., Snijkers, F. and Verberckmoes, A. (2019) Sustainable iron-based oxygen carriers for Chemical Looping for Hydrogen Generation. International Journal of Hydrogen Energy, 44, 1374-91. https://doi.org/10.1016/j.ijhydene.2018.11.099 